\title{
1.1 Exploring the Politico-institutional Dimension of Social Innovation to Repoliticize Urban Governance Arrangements
}

\author{
Angeliki PaIDAKakI, Frank MoulaERT, Pieter VAN DEN Broeck \\ Research Unit Planning and Development, Department of Architecture, \\ University of Leuven
}

\section{Introduction}

A central proposition of this paper is that any transition initiative and governance arrangement is inevitably confined within - or dictated by - neoliberal and financialization market logics, which themselves resist their own transition (SwYNGEDouw 2010). Institutional structures ${ }^{1}$ and socially innovative groups which do not - or insufficiently - challenge the larger political economy that frames social services systems (including housing systems) will constantly find themselves interacting in post-political, consensusoriented governance arenas. The 'participation' of some groups might improve governance temporarily (by allowing those groups to seize certain opportunities), but real egalitarian urbanities in their pluralism and heterogeneity are covered up when not seen in their openness as a political universal ideal.

We reached this proposition after posing ourselves the following question: "Can social innovation have a socio-political transformative impact?". According to a range of post-political foundational authors (such as Metzger, Mouffe, Rancière, Swyngedouw and WILSON), social innovation can only have limited potential for socio-political transformation. Why do they argue this? Because they are tempted to refer to 'caring neoliberal' views of social innovation. Within a 'caring neoliberal' paradigm the welfare

Public or state entities (state agencies, governmental authorities, elected officials) and private bodies (lobbying firms, foundations, faith-based organizations, intermediaries, financial institutions, industry associations). 
state is shrunken in budget and social responsibility for cost-efficiency purposes. The new main role of the small welfare state becomes the activating and monitoring preselected civic society groups with fixed identities (NGOs, business groups), who in turn are expected to experiment with new ideas for providing low-cost social services. In governance terms, this paradigm translates into a-political, techno-managerial and consensus-oriented elitist governance arrangements that cultivate politically modest social service providers and pre-define linear and mono-directional urban development trajectories that ultimately sharpen inequality in urban society.

Nevertheless, the 'caring neoliberalism' view of social innovation is one among many put forward in the admittedly confusing debate on social innovation. While recognizing the double-edged character of socially innovative forms of urban development and governance with some initiatives being considered too reformist and compliant with neoliberal logics (SwYNGEDOuw 2009), in fact, in urban studies and planning social innovation has been a trigger for renovating and reinventing the political in planning (MetzGer et al. 2014; Moulaert 2013; Moulaert et al. 2007; SMith et al. 2014; RACO 2007). By putting more stress on the political dimension of social interactions, the notions of dissensus, contestation and empowerment (in the form of invigorated political capabilities to access necessary resources) are highlighted. In this respect, the right to participate in the urban (re)production is not by any means pregiven. On the contrary, socially innovative groups are constantly confronted with the challenge to claim their right to participate in public arenas and transform their own transition initiatives to socio-political transformations that would become beneficial to larger parts of the population.

Prominent scholars belonging in the 'radical' or 'democratic' tradition of the social innovation debate have used the concept from a political economy point of view by working with the three-dimension definition, the third dimension being empowerment and socio-political transformative potential (MacCallum 2009; Moulaert et al. 2005, 2007, 2013; OOSTERLYNCK et al. 2013a,b). In this paper, we focus on this transformative dimension of social innovation and seek to find an answer to the following question: "How can radical social innovation have a socio-political transformative impact?". In this pursuit, we first gain insights from previous theoretical work on social innovation in bottom-linked governance and then examine empirically how and to what extent socially innovative rebuilding initiatives in post-Katrina New Orleans have had a sociopolitical transformative impact. We specifically shed light on three potentialities of social innovative initiatives: i) the correction of enduring power asymmetries across social groups participating in the urban (re)development process (i.e. institutional structures, business communities, non-governmental organizations, activist groups), ii) the induction of institutional changes in governance arrangements and iii) the leadership of alternative development trajectories in the (re)production of cities. 


\section{Radical social innovation and bottom-linked governance: some theoretical insights}

The literature on radical social innovation is theoretically diverse and interdisciplinary with a special socio-spatial focus on community development concerns (Moulaert et al. 2013; Oosterlynck et al. 2013a,b). Situated within the broader tradition of critical studies, this literature underscores the political essence of innovative actions (discursive and material) taken by grassroots groups, and gives prominence to empowerment, solidarity and criticism against the socio-economic inconsistencies and disrupting socio-political, cultural and bio-physical consequences of neoliberal forms of urban development (Moulaert et al. 2007 in Paidakaki and Moulaert 2017b). By scrutinizing this literature, two main observations emerge: i) alternative organizations reinvent the principles of democracy, self-governance and solidarity and ii) by applying these reinvented principles of the grassroots democracy, the principle of bottom-linked governance materializes. More specifically:

1) Transformational change triggered by micro-initiatives in the name and on the basis of solidarity goes beyond the establishment of new collaborations between organizations and sectors. Indeed, as many neighborhood development projects and neighborhood grassroots initiatives across the world showcase, there are various degrees of urban activism that regain the political, form new arenas and work out socially innovative strategies for spatial development. Some illustrative examples of such socially innovative initiatives are documented in the book Can Neighbourhoods Save the City?: Community development and social innovation by MOULAERT et al. published in 2010 (i.e. the Centro Sociale Leoncavallo and Olinda in Milano, the Associazone Quartieri Spagnoli in Naples, the Alentour Association in Roubaix, the Arts Factory in Ferndale, the Ouseburn Trust and the New Deal for Communities in Newcastle, the City Mine(d) in Brussels, the BOM in Antwerp), as well as in the book Social Innovation and Democratic Leadership: Communities and Social Change from Below by PARÉS et al. published in 2017 (i.e. Small Business United, the Ecostation, Los Quedamos and the South Bronx Unite in New York, and the Centre Cruilla, the 50X20, the Can Batllo and the Platform for Mortgage Affected People in Barcelona). All these examples validate the presumption that social innovation in reinventing and (re)politicizing governance is without doubt extremely important.

2) Solidarity-inspired socially innovative actions cannot take place in a vacuum but need to be embedded in bottom-linked governance structures in order to have a lasting impact on the functioning of democracy. This embeddedness mainly translates into the recognition and constant promotion of the centrality of those initiatives by institutional structures through sound and productive regulatory and legislative frameworks and new governance arrangements (OOSTERLynCK et al. 2013a citing Moulaert 2010). In other 
words, in the presence of strong and uninterrupted mobilization and active citizenship, citizens can shape new governance arrangements by forcing institutional structures i) to create new mechanisms for the provision of resources, ii) to imagine new ways of conceptualizing and approaching policy problems and iii) to engage with and empower a wider range of policy implementers and civic actors to develop socially innovative practices (PRADEL et al. 2013). Thus, bottom-linked governance becomes a transversal institutionalization of social change that is materialized through constant and varied interactions between socially innovative actors and institutional structures. Numerous examples of bottom-linked governance interactions can be found in the works of Marc Pradel, Santiago Eizaguirre and Marisol García (Eizaguirre et al. 2012; García et al. 2015; Pradel et al. 2013).

To better analyze and theorize the political praxis of socially innovative actors and understand the politics of urban transition, we make use of the concept of 'social resilience cells' (SRCs) developed by PAIDAKAKI and MoulaERT (2017a,b). SRCs are defined as affordable housing providers or housing policy implementers who organize themselves actively and discursively with the aim to influence the development profile of a city. Through the lenses of the 'SRCs', we make an effort to uncover and critically analyze the various interactions between housing policy implementers and institutional structures and the resulting politico-institutional transformations and 'bouncing forward' urban (re)development possibilities resulting from those interactions. To concretize this discussion, we draw on empirical material from Angeliki PAIDAKAKI's doctoral research on post-Katrina recovery in New Orleans.

\section{SRCs and housing rebuilding in post-Katrina New Orleans}

This section aims to investigate how and to what extent socially innovative rebuilding initiatives in post-Katrina New Orleans have had a socio-political transformative impact. In previous research, we have identified SRCs as the main actors of the housing rebuilding process in post-Katrina (PAIDAKAKI and Moulaert 2017b; PAIDAKAKI and PARRA 2018). The distinction is made between three categories of SRCs that occupy different positions in the contentious and institutionally diverse housing arenas and interact with the social and political regime in varied ways.

The more conservative/hegemonic pro-growth SRCs (i.e. for-profit real-estate developers) treat houses as profitable commodities and work closely with powerful institutions (such as real-estate agencies, banks, state agencies, think tanks, lobby groups and elected officials) with the aim to maintain and reinforce deregulation and marketfriendly laws and institutions. The majority of those SRCs are, hence, system conforming and sit comfortably within a 'caring neoliberal' state that promotes a for-profit business 
regulatory and legislative environment (or in the worst case a speculation-oriented pattern of profit accumulation, also known as financialization) (AALbers 2008; Cullingworth and Caves 2014; Gotham 2012; Johnson 2011; Raco 2013 cited in Paidakaki and Parra 2018). The more progressive/alternative pro-equity and pro-comaterializing SRCs (i.e. nonprofit real-estate developments, community development corporations, community land trusts and, housing cooperatives) prioritize the 'quality-of-life' aspect of housing and advocate for housing rights and diversity of tenure. Their main purpose is to (re) build housing and infrastructure in a way that would satisfy the housing needs of people who do not have the economic resources to house themselves by their own means. By working closely with charitable foundations, intermediary groups, elected officials, state agencies and other social movements and NGOs, alternative SRCs' main ambition is to challenge the system, introduce new legal regulations and housing finance tools and programs and change or improve the modes of interactions between and across SRCs and institutional structures.

In the immediate aftermath of the Katrina disaster, the preferred governmental financial tools and actions for the recovery of New Orleans followed the path dependencies of a well-established new urban policy agenda favoring the discursive and material practices of pro-growth SRCs (BOND GRAHAM 2011; OLSHANSKY and JoHNSON 2010; SeIdman 2013 cited in Paidakaki and Moulaert 2017b). After vigorous lobbying activities by conservative organizations based in Washington DC (i.e. the Manhattan Institute, the American Enterprise Institute, the Heritage Foundation), the Congress formulated a policy and legislative framework promoting market tools (i.e. tax-exempt private activity bonds and low-income housing tax credits) that are more familiar to the pro-growth housing community. Pro-growth SRCs were further favored by the decision of the federal authority of housing and urban development (HUD) to demolish and redevelop New Orleans' four public housing developments into mixed-income communities with HOPE VI funding. This decision by HUD was premised on a chronic rationale that public housing is emblematic of concentrated urban poverty and mirrors a long-established US experimentation with New Urbanism (NU) design ideas (BUTTON and Oliver-Smith 2008; Gotham and Campanella 2011 in Paidakaki and Moulaert 2017b). The funding opportunity resulting from this federal decision bolstered progrowth SRCs' enduring plans to transform real-estate use values into exchange values for private developers through the revamping of public housing (ARENA 2012; Bond GRAHAM 2011).

At the local level, interactions between pro-growth SRCs and institutional structures as well as the results of such interactions come bolder to the fore. One emblematic case of those interactions in the early recovery years was the Bring New Orleans Back (BNOB) plan. The main observation about the BNOB plan is the orchestrated intention of a powerful and well-connected local developer who chaired the recovery planning committee to radically restructure the city's urban structure and produce new forms of investment for the benefit of pro-growth SRCs (see also OLSHANSKY and JoHnSON 
2010). Together with the Urban Land Institute, the developer recommended a strategic reconstruction plan that prioritized immediate rebuilding of those areas that went through minimal damage. A similar planning rationale emerged in the late recovery years by other pro-growth alliances. Under the new city administration elected in 2010 , post-Katrina redevelopment was restrategized on the basis of a 'place-based' approach. References to the value of this approach are traced in various documents, including the famous article Return to Splendor written in 2010 by the influential president of a local pro-growth SRC and proponent of NU principles, and the City's Blight Reduction Report (PAidakaki and Moulaert 2017b).

Over the early and late recovery years, the aforementioned pro-growth transition tendencies did not go unchallenged. The BNOB plan controversy as well as the federal decision to demolish the local public housing estates spurred a series of civic actions including protests, the establishment of neighborhood associations, the development of neighborhood plans and the growth of an impressive number of alternative SRCs (PAidakaki and Moulaert 2017b). In the early recovery years, many of the newly formed and pre-existing alternative SRCs set up their own alliance (the Greater New Orleans Housing Alliance - GNOHA) to improve collaboration in the rebuilding process and advocate for the benefit of the most vulnerable. This emerging local capacity was quickly recognized by a few institutional structures. For instance, at the recovery outset, the Enterprise Community Partnership (a national nonprofit intermediary group) set up an office in New Orleans and started working exclusively with alternative SRCs to build affordable rental housing for the low-and-middle-income population. Enterprise has also become the federal voice of those SRCs in the Congress (PAIDAKAKI and PARRA 2018). The New Orleans Office for Community Development also responded to the urgent call made by many alternative SRCs to develop a finance tool for gap financing. In the late recovery years, alternative SRCs and their alliance gained stronger professional skills and reputation. HousingNOLA, GNOHA's broad-based initiative taken in 2014, has stood out as an emblematic housing arena in which a wide range of stakeholders (i.e. public officials, community leaders, neighborhood associations, financial institutions, policy-makers, special needs advocacy groups, nonprofit and for-profit developers) got involved with the aim to co-produce and implement a community-led plan that identifies and meets the housing needs of all of New Orleans for the years 2015-2025.

As a result of various interactions between and across alternative SRCs, their allies and institutional structures, a series of multi-level institutional transformations have occurred. Specific references to the essential role of nonprofits in disaster housing can be read in the National Disaster Recovery Framework ${ }^{2}$, the Louisiana Homeland

2 "Recovery Support Functions involve partners in the local, State and Tribal governments and private and nonprofit sectors not typically involved in emergency support functions but critically needed in disaster recovery. These new partners may include public and private organizations that have experience with permanent housing financing, economic development, advocacy for underserved populations and long-term community planning." (Housing Recovery Support Function: https://www.fema.gov/recovery-support-functions) 
Security and Emergency Assistance and Disaster $\mathrm{Act}^{3}$, the draft consolidated annual action plan for housing and community development of $2014^{4}$, the nonprofit rebuilding pilot program and the Homeowner Rehabilitation Program ${ }^{5}$ (PAIDAKAKI and PARRA 2018). The geographical and institutional proximity between institutional structures and SRCs based in New Orleans played an important role in fostering a culture of exchange and deeper understanding of the distinctive advantages and inconveniences of a diverse landscape of SRCs (ibid). This has resulted in a noticeable overall improved governance structure, as is best witnessed in the case of HousingNOLA.

In a nutshell, the general observation regarding the nature of actions and interactions of SRCs with institutional structures in the post-Katrina recovery years is that progrowth rebuilding trajectories were largely bold and pre-destined by path dependencies in the US housing policy and governance. However, alternative SRCs and their alliance, operating increasingly in a socially innovative way, have managed to reverse some of the pre-destined pro-growth trends, alter housing governance configurations and set in motion alternative recovery potentialities (PAIDAKaKi and MoulaerT 2017b). Yet, considering the nature of the manifested institutional transformations, the question still remains: "Can we claim that alternative SRCs in New Orleans have had a socio-political transformative power to shape respectful and productive frameworks for all SRCs on the ground?" Part of the final concluding section aims to answer this question.

\section{Conclusions}

The late post-Katrina recovery era is characterized by an increasing local prominence of alternative SRCs. Nevertheless, despite this prominence, alternative SRCs have tripped over the rigid foundations of the current US housing finance system and

3 "The legislature finds that resources of nongovernmental nonprofit organizations can contribute greatly to the state's formalized framework for implementation of the requirements of this Chapter. Inclusion of the efforts of nongovernmental nonprofit organizations in the state's emergency preparedness, response, and recovery plans to the greatest extent predictable is encouraged." (http://www.legis.la.gov/Legis/Law.aspx?d=452286)

$4 \quad$ "A strategy to address the needs of the homeless and the at risk population, and to recognize the special needs of the various types of homeless individuals, must take into account the primary role of community-based charitable organizations and voluntary programs, alone or in partnership with local governments and public agencies, in establishing and supporting basic facilities and services for the homeless." (Last accessed in August 2014)

$5 \quad$ "In hurricane-impacted areas, successful models have been developed by CDCs and other non-profits to secure and leverage resources in order to meet the needs of homeowners to complete their rebuilding process... The state has long recognized the success of these entrepreneurial efforts and has sought to secure funding for these programs to continue their efforts to help homeowners recover." (Action Plan Amendment 33 (First Allocation) - Nonprofit Rebuilding Pilot Program: http://www.doa.la.gov/OCDDRU/Action\%20Plan\%20Amendments/Katrina-Rita\%20First/ APA33_Approved.pdf) 
proved to be less successful in blocking off caring neoliberal trends that undercut the welfare system.

Alternative SRCs have mainly worked under the given macro-financial mechanisms and were unsuccessful in triggering structural changes in the US housing system and the socio-political system as a whole. State agencies, elected officials and other institutional structures have similarly limited their actions within the constraints of the given housing finance paradigm. In the absence of a substantially welfare-oriented frame, any ambitious societal goals of resilience pursued by policy makers, state agencies, elected officials and other institutional structures and SRCs cannot be truly materialized (PAIDAKAKI and PARRA 2017). The primary structural constraint is the fact that the finance model for lowincome housing in the US is based on leveraging; namely, a combination of (unstable/ insufficient) direct subsidies provided by federal agents and administered by state and local administrative agents, indirect expenditures (i.e. low-income housing tax credits) and other private and charitable donations (corporations, faith-based groups, foundations) and/or mortgages (ibid.). As opposed to direct deep state subsidies, this finance model not only forces all SRCs to go through a hectic, technically demanding and time-consuming exercise, but it also reflects a lack of serious institutional commitment to fight housing exclusion and bolster the capacities of alternative SRCs. As a result, the majority of those SRCs are constantly at risk of being undercapitalized. The pro-growth SRCs, on the contrary, sit more confidently in market-mediated financialization processes and are in a more privileged position to access and leverage sufficient funding for the production of affordable housing (ibid.). This asymmetry of capacities to access resources among SRCs implies that in the absence of complementary value systems characterizing the US political economy (mutuality, reciprocity and social solidarity beyond profit) the current shallow and disrupted subsidies will continue to put at risk the survival of alternative SRCs and the production of a sufficient affordable housing inventory (PAIDAKAKI and PARRA 2018; see also DAvis 2006). Such an oppression of social innovation in housing systems draws a red line for the expansion of future possibilities.

To overcome such an oppression, any serious and honest discussion on the sociopolitical transformative potential of radical social innovation should go hand in hand with a politicized deliberation on alternative visions of the state (PAIDAKAKI and PARRA 2018) and its social practices in guiding the heterogeneous development of cities. Such a model of governance, in post-foundational terms, underscores the process of effectuation (Moyersoen and Swyngedouw 2013), whereby the new state apparatus becomes the liberating agent of the plurality of SRCs on the ground (see also CLARK and DeAr 1984 in Paidakaki and Parra 2018). In material and institutional terms, the new 'neo-welfare' state can truly liberate this pluralism through massive social investments fairly distributed across a diverse terrain of SRCs, and fundamental legislative and policy reforms which expand alternative economic forms of housing provision (PAIDAKAKI and PARRA 2018).

Future research on the complex and heterogeneous spatio-temporal realities of social innovation at the micro level and institutional settings that foster or contain 
social innovative productive forces at the macro level will better uncover the conflictual relationships between the political ambition of social innovation and the post-political, neoliberal governance paradigm. This relevation will hopefully provide inspiration for the genesis of improved governance structures that are post-foundational and neo-welfare, with an eye towards the imagination and the material production of real egalitarian urbanities.

\section{References}

Aalbers M.B. (2008), The financialization of home and the mortgage market crisis. Competition \& change 12(2), pp. 148-166.

Arena J. (2012), Driven from New Orleans: How nonprofits betray public housing and promote privatization. Minneapolis, MN, University of Minnesota Press.

Bond Graham D. (2011), Building the New New Orleans: Foundation and NGO Power. The Review of Black Political Economy 38, pp. 279-309.

Button G.V., \& Oliver-Smith A. (2008), Disaster, Displacement and Employment: Distortion in Labor Markets in Post-Katrina Reconstruction. In: Gunewardena N., \& Schuller M. (eds.), Capitalizing on Catastrophe: The Globalization of Disaster Assistance. Lanham, New York, Toronto, Plymouth (UK), AltaMira Press, pp. 123-145.

Clark G.L., \& Dear M.J. (1984), State Apparatus: Structures and Language of Legitimacy. Hemel Hempstead, Hertfordshire, Allen \& Unwin.

Cullingworth J.B., \& CAves R. (2014), Planning in the USA: policies, issues, and processes. London and New York, Routledge.

Davis J.E. (2006), Between Devolution and the Deep Blue Sea: What's a City or State to Do? In: Bratt R.G., Stone M.E., \& Hartman C.W. (eds.), A right to housing: Foundation for a new social agenda. Philadelphia, PA, Temple University Press, pp. 364-398.

Eizaguirre S., Pradel M., Terrones A., Martinez-Celorrio X., \& García, M. (2012), Multilevel governance and social cohesion: Bringing back conflict in citizenship practices. Urban Studies 49(9), pp. 1999-2016.

García M., Eizaguirre S., \& Pradel M. (2015), Social innovation and creativity in cities: A socially inclusive governance approach in two peripheral spaces of Barcelona. City, Culture and Society 6(4), pp. 93-100.

Gотнам K.F. (2012), Disaster, inc.: Privatization and post-Katrina rebuilding in New Orleans. Perspectives on politics 10(3), pp. 633-646.

Gotham K.F., \& Campanella R. (2011), Coupled vulnerability and resilience: the dynamics of cross-scale interactions in post-Katrina New Orleans. Ecology and Society 16(3): 12. DOI: 10.5751/ES-04292-160312

Johnson C. (2011), Charming Accommodations: Progressive Urbanism Meets Privatization in Brad Pitt's Make It Right Foundation. In: Johnson C. (ed.), The Neoliberal Deluge: Hurricane Katrina, Late Capitalism, and the Remaking of New Orleans. Minneapolis, MN, University of Minnesota Press, pp. 187-224.

MacCallum D., Moulaert F., Hillier J., \& Vicari Haddock S. (eds.), (2009), Social innovation and territorial development. Farnham, Ashgate Publishing Limited. 
Metzger J., Allmendinger P., \& Oosterlynck S. (2015), Planning against the political: Democratic deficits in European territorial governance. London, Routledge.

Moulaert F., MacCallum D., Mehmood A., \& Hamdouch A. (eds.), (2013), The International Handbook on Social Innovation: Collective Action, Social Learning and Transdisciplinary Research. Cheltenham, Edward Elgar Publishing Limited.

Moulaert F., Martinelli F., Swyngedouw E., \& González S. (2005), Towards alternative model(s) of local innovation. Urban Studies 42(11), pp. 1969-1990.

Moulaert F., Martinelli F., González S., \& Swyngedouw E. (2007), Introduction: Social innovation and governance in European cities: urban development between path dependency and radical innovation. European Urban and Regional Studies 14(3), pp. 195-209.

Moulaert F., Swyngedouw E., Martinelli F., \& Gonzalez S. (eds.), (2010), Can Neighbourhoods Save the City? Community development and social innovation. Abingdon, Routledge.

Moyersoen J., \& Swyngedouw E. (2013), LimiteLimite: Cracks in the City, Brokering Scales, and Pioneering a New Urbanity. In: Nicholls W., Miller B., \& Beaumont J. (eds.), Spaces of Contention: Spatialities and Social Movements. London, Routledge, pp. 141-162.

Olshansky R.B., \& Johnson L.A. (2010), Clear as Mud: Planning for the Rebuilding of New Orleans. Chicago and Washington, DC, American Planning Association.

Paidakaki A., \& Moulaert F. (2017a), Does the post-disaster resilient city really exist? A critical analysis of the heterogeneous transformative capacities of housing reconstruction "resilience cells". International Journal of Disaster Resilience in the Built Environment 8(3), pp. 275-291.

Paidakaki A., \& Moulaert F. (2017b), Disaster Resilience into Which Direction(s)? Competing Discursive and Material Practices in Post-Katrina New Orleans. Housing, Theory and Society, pp. 1-23.

Paidakaki A., \& Parra C., (2018), "Housing for all" at the era of financialization; Can (postdisaster) cities become truly socially resilient and egalitarian? (Work in progress)

Parés M., Ospina S.M., \& Subirats J. (eds.), (2017), Social Innovation and Democratic Leadership: Communities and Social Change from Below. Cheltenham, Edward Elgar Publishing Limited.

Pradel M., Cabeza M.G., \& Anglada S.E. (2013), Theorizing multi-level governance in social innovation dynamics. In: Moulalert F., MacCallum D., Mehmood A., \& Hamdouch, A. (eds.), The International Handbook on Social Innovation: Collective Action, Social Learning and Transdisciplinary Research. Cheltenham, Edward Elgar Publishing Limited, pp. $155-168$.

RACO M. (2007), Securing sustainable communities: citizenship, safety and sustainability in the new urban planning. European Urban and Regional Studies 14(4), pp. 305-320.

Raco M. (2013), State-led Privatisation and the Demise of the Democratic State: Welfare Reform and Localism in an Era of Regulatory Capitalism. Farnham, Ashgate.

Seidman K.F. (2013), Coming Home to New Orleans: Neighborhood Rebuilding After Katrina. Oxford and New York, Oxford University Press.

Smith A., Fressoli M., \& Thomas H. (2014), Grassroots innovation movements: challenges and contributions. Journal of Cleaner Production 63, pp. 114-124.

Swyngedouw E. (2009), Civil society, governmentality and the contradictions of governancebeyond-the-state: the Janus-face of social innovation. In: MacCallum D., Moulaert F., Hillier J., \& Vicari Haddock S. (eds.), Social Innovation and Territorial Development. Farnham, Ashgate Publishing Limited, pp. 63-78. 
Swyngedouw E. (2010), Impossible sustainability and the post-political condition. In: Cerreta M., Concilio G., \& Monno V. (eds.), Making Strategies in Spatial Planning. Dordrecht: Springer Netherlands, pp. 185-205.

\section{Online References}

Oosterlynck S., Kazepov Y., Novy A., Cools P., Barberis E., Wukovitsch F., \& Leubolt B. (2013a), The butterfly and the elephant: local social innovation, the welfare state and new poverty dynamics. Research Project ImPRovE Working Paper. PDF: improve-research.eu/ ?wpdmact $=$ process $\&$ did $=$ MjAuaG90bGluaw $==$ [Last accessed on 03-10-2017]

Oosterlynck S., Kazepov Y., Novy A., Cools P., Wukovitsch F., Saruis T., \& Leubolt B. (2013b), Exploring the multi-level governance of welfare provision and social innovation: welfare mix, welfare models and rescaling 13(12). Herman Deleeck Centre for Social Policy, University of Antwerp. PDF: improve-research.eu/?wpdmact=process\&did=MzMuaG90b Gluaw $==[$ Last accessed on 03-10-2017] 
